\title{
Forberedende samtaler i norske sykehjem
}

\begin{abstract}
BAKGRUNN Sykehjemspasienter er ofte skrøpelige og har flere kroniske lidelser. Økt risiko for kritiske hendelser, sykehusinnleggelser og død peker på behovet for samtaler med pasient og pårørende om tiden fremover, hvordan man skal bli enig om gode beslutninger og hva som skal skje hvis helsetilstanden forverres. Tidligere studier har vist at et mindretall av sykehjemmene praktiserer slike forberedende samtaler.
\end{abstract}

MATERIALE OG METODE En spørreskjemaundersøkelse ble forsommeren 2014 sendt til alle sykehjem i Norge. Det ble spurt om forekomst av og innhold i forberedende samtaler.

RESULTATER Det kom svar fra $57 \%$ av sykehjemmene (486 sykehjem). Omtrent to tredeler rapporterte at de «alltid» eller «som oftest» gjennomførte forberedende samtale og omtrent en tredel av dem hadde skriftlige retningslinjer. Samtalene fant først og fremst sted når pasientens helsetilstand ble forverret, når pasienten gikk inn i siste livsfase eller i forbindelse med innkomstsamtalen. Sykehusinnleggelse, smertelindring og hjerte-lunge-redning (HLR) var de hyppigste temaene. Pårørende og sykehjemslege deltok som oftest i samtalene, pasientene deltok mer sjeldent.

FORTOLKNING Det var store variasjoner mellom sykehjemmene når det gjaldt forberedende samtaler. Dette kan dels forstås på bakgrunn av mangel på nasjonale retningslinjer, dels at dette er en relativ ny diskusjon i Norge. At pasientene sjelden deltok i samtalene, har trolig sammenheng med at det hos disse er en høy andel med kognitiv svikt, at legedekningen er lav og at det er en mangelfull kultur for pasientmedvirkning.

Omtrent $47 \%$ av alle dødsfall i Norge i 2013 fant sted i sykehjem (1). En økende andel sykehjemspasienter med kognitiv svikt (2), og et høyt antall kritiske hendelser, som akutt forverring av helsetilstanden, representerer utfordringer i forhold til å gi pleie og behandling i tråd med pasientens ønsker og verdier. For at de medisinske beslutninger som fattes skal være i tråd med etikk og lovverk, er det viktig at pasientene får uttrykt sine ønsker i tide. Er det noe de frykter, hvor mye informasjon ønsker de, hvordan ønsker de selv at deres pårørende skal bli involvert $\mathrm{i}$ beslutninger? Og finnes det helsehjelp de ikke vil ha?

Pasientens preferanser innen pleie og behandling kan avdekkes gjennom en «forberedende samtale» (advance care planning, ACP). Slike samtaler kan dreie seg om sykehusinnleggelser, livsforlengende behandling, symptomlindring, livets sluttfase og mer eksistensielle spørsmål $(3,4)$.

Det siste tiåret er det i en rekke vestlige land blitt vanlig å registrere bruken av ulike former for forberedende samtaler $(3,4)$. I Helsedirektoratets veileder for beslutningsprosesser for begrensning av livsforlengende behandling vektlegges gode rutiner for å fremme pasientens selvbestemmelse, og man anbefaler blant annet en forberedende samtale når pasientens liv nærmer seg slutten (5).

En studie fra 2007 viste imidlertid at man ved svært få sykehjem i Norge praktiserte denne type samtaler (6). I en kvalitativ studie blant sykehjemspasienter og pårørende få år senere fant man at mens noen pasienter ønsket en slik samtale, mente andre at det ikke var nødvendig. Nesten alle de 33 pårørende i studien ønsket slike samtaler (7). En studie av samtaler om fremtidig helsehjelp og informasjon $i$ en akuttgeriatrisk sengepost viste at omtrent fire femdeler av pasientene opplevde det som positivt å snakke om disse temaene (8).

I perioden 1990-2015 ble det publisert flere systematiske oversikter med vekt på forberedende samtaler i sykehjem (9-16). Sharp og medarbeidere fant at $60-80 \%$ av de gamle selv ønsket å diskutere disse spørsmålene (12). van der Steen og medarbeidere så på hvilke forhold som fremmer denne type samtaler hos pasienter med demens og deres pårørende og konkluderte med at helsepersonell burde ta initiativet (13). Man må være sensitiv når det gjelder valg av tidspunkt og åpen for respons fra pasienter og pårørende. Bruk av forberedende samtaler kan blant annet føre til bedre dokumentasjon av pasientens preferanser, at man kan gi en pleie mer i tråd med pasientens ønsker, føre til reduksjon i antall sykehusinnleggelser og en mer egnet bruk av hospice og palliativ behandling (9-16).

Vi ønsket i denne studien å kartlegge forekomsten av og gjennomføringen av forberedende samtaler i samtlige norske sykehjem.

\section{Materiale og metode}

Spørreskjemaet ble først sendt til ti sykehjem og deretter justert ved å føye til flere svaralternativer. Skjemaet består av 19 spørsmål om blant annet forekomst av og innhold i forberedende samtaler, hvem som deltok, eventuell eksistens av skriftlige retningslinjer for

\author{
Elisabeth Gjerberg \\ elisabeth.gjerberg@medisin.uio.no \\ Lillian Lillemoen \\ Kristin Weaver \\ Reidar Pedersen \\ Reidun Førde \\ Senter for medisinsk etikk \\ Universitetet i Oslo
}

Spørreskjemaet finnes på

tidsskriftet.no/gjerbergappendiks

TL

Engelsk oversettelse på www.tidsskriftet.no

\section{HOVEDBUDSKAP}

Et stort antall sykehjem praktiserte en form for forberedende samtale, men det var stor variasjon med hensyn til tidspunkt, innhold og hvem som deltar

Et mindretall av sykehjemmene hadde retningslinjer for slike samtaler

Det var først og fremst pårørende og sykehjemslegen som deltok, sykehjemspasientene deltok sjeldnere

Pasientdeltagelsen økte med sykehjemmets legedekning 
Tabell 1 Temaer som tas opp i forberedende samtaler. Basert på spørreskjema besvart ved 486 sykehjem

\begin{tabular}{lc}
\hline Tema & $\begin{array}{c}\text { Andel angitt } \\
\text { i prosent }\end{array}$ \\
Sykehusinnleggelse & 87 \\
Smertelindring & 83 \\
HLR-status & 79 \\
Bruk av antibiotika & 75 \\
Kunstig ernæring & 63 \\
Andre spørsmål knyttet & \\
til livets sluttfase og døden & 47 \\
\hline
\end{tabular}

samtalene og hvor ofte de ble dokumentert (se gjerbergappendiks).

«Forberedende samtale» ble definert som «en samtale der pasient og/eller pårørende sammen med ansatte prøver å få frem pasientens ønsker for fremtidig behandling, pleie og omsorg hvis helsetilstanden forverres». Det ble også spurt om man foretok innkomstsamtaler og hva som ble tatt opp i disse.

Alle norske sykehjem fikk tilsendt spørreskjemaet våren 2014, stilet til institusjonssjef/enhetsleder. Kun sykehjem med langtidsavdelinger ble inkludert - totalt 848 . Resultatene er beskrevet med enkle statis- tiske analyser i SPSS, versjon 22. Forskjeller mellom grupper er foretatt ved bivariate analyser med khikvadrattest.

Undersøkelsen inneholder ikke personidentifiserbare opplysninger og er derfor ikke meldepliktig til Norsk senter for forskningsdata (NSD), tidligere Norsk samfunnsvitenskapelig datatjeneste, eller regional etisk komité.

\section{Resultater}

Etter to purringer mottok vi svar fra totalt 486 sykehjem $(57,3 \%)$. Alle fylker var representert. Spørreundersøkelsen var stilet til sykehjemmets ledelse, med oppfordringen om å innhente informasjon hos andre dersom de selv ikke hadde tilstrekkelig kunnskap. De som svarte var enten leder ved sykehjemmet (48\%), avdelingsleder (35\%), fagansvarlig eller sykepleier (13\%) eller sykehjemslege $(8 \%)$.

Sykehjemmene hadde i gjennomsnitt 47,5 senger (spredning 6-182 senger). Gjennomsnittlig antall legetimer i uken var 0,37 timer per seng (median 0,31 t, spredning 0,01$1,94 \mathrm{t})$.

\section{Forberedende samtaler - \\ forekomst og retningslinjer}

En femdel av sykehjemmene (20\%) svarte at de «alltid» praktiserer en forberedende samtale, $44 \%$ svarte at de «som oftest» gjennomfører dette, $28 \%$ svarte «av og til» og $7 \%$ svarte «sjelden/aldri».

Tabell 2 Deltagere i forberedende samtaler. Basert på spørreskjema besvart ved 486 sykehjem

\begin{tabular}{lccccc} 
Deltagere & $\begin{array}{c}\text { Som oftest } \\
(\%)\end{array}$ & $\begin{array}{c}\text { Av og til } \\
(\%)\end{array}$ & $\begin{array}{c}\text { Sjelden/aldri } \\
(\%)\end{array}$ & $\begin{array}{c}\text { Vet ikke } \\
(\%)\end{array}$ & $\begin{array}{c}\text { Antall sykehjem }{ }^{1} \\
\text { (n) }\end{array}$ \\
Pasient & 37,7 & 42,2 & 20 & 0,2 & 446 \\
Pårørende & 93,2 & 6,6 & - & 0,2 & 456 \\
Avdelingsleder & 44,4 & 34,4 & 20,9 & 0,2 & 401 \\
Sykehjemslege & 79,1 & 17,3 & 3,2 & 0,5 & 444 \\
Primærkontakt & 64,4 & 28,4 & 6,4 & 0,7 & 419 \\
\hline
\end{tabular}

${ }^{1}$ Kolonnen angir antall sykehjem som krysset av for ett av alternativene på de ulike deltagerne

Tabell 3 Når fant forberedende samtaler sted? Basert på spørreskjema besvart ved 486 sykehjem

\section{Tidspunkt}

Andel (\%)

Ved forverring av pasientenes helsetilstand

75,7

Når det antas at pasienten går inn i siste livsfase

Kort tid etter innkomst

Ved årskontroller

44,4

42,4

Flere ganger, som del av en prosess
Av dem som praktiserte forberedende samtaler «alltid»/《som oftest»/《av og til»», svarte $34 \%$ at de har skriftlige retningslinjer for denne type samtaler. De som «alltid» praktiserte slike samtaler, svarte oftere at de har retningslinjer $(67 \%)$ enn de som praktiserte dette «som oftest» $(33 \%)$ eller «av og til» $(13 \%)(\mathrm{p}<0,005)$. Ved sykehjem med høy legedekning ble det gjennomført signifikant flere slike samtaler enn ved sykehjem med lav legedekning ( $\mathrm{p}<0,05)$.

$\mathrm{Vi}$ ba om å få tilsendt retningslinjene fra ca. $20 \%$ av dem som svarte at de hadde slike (28 sykehjem). Vi mottok 11 svar. I fem av dem var det retningslinjer som inkluderte pasientens ønsker om fremtidig helsehjelp.

\section{Innhold $i$ samtalene}

Tabell 1 viser at et stort flertall tar opp spørsmål om henholdsvis sykehusinnleggelse, smertelindring og hjerte-lunge-redning (HLR). Litt under halvparten (47\%) svarte at også «andre spørsmål knyttet til livets sluttfase og døden» tas opp.

Respondentene utdypet dette i fritekst, og svarene grupperte seg i tre hovedkategorier: pårørendes rolle, åndelige/eksistensielle spørsmål, ivaretagelse av pasientens ønsker og interesser. Mer sjelden nevnes væskebehandling, forventet forløp i en demensutvikling og hva som skjer i en terminal fase.

\section{Hvem deltar og når?}

Som tabell 2 viser er det forst og fremst pårørende og sykehjemslege som deltar, pasientene er sjeldnere med. Pasienter ved sykehjem med høy legedekning deltar signifikant oftere i samtalene enn pasienter ved sykehjem med lav legedekning ( $\mathrm{p}<0,001)$.

Forverring av pasientens helsetilstand $(76 \%)$ og antagelse om at pasienten går inn i siste livsfase $(59 \%)$ er det som oftest gir grunnlag for slike samtaler. I tillegg kombineres samtalene noen steder med årskontroller (tab 3).

I underkant av 30\% svarte at samtalene ble gjennomført flere ganger, som del av en prosess. Dette foregikk signifikant oftere i sykehjem der de oppga at de hadde skriftlige retningslinjer for slike samtaler enn i andre sykehjem, henholdsvis $40 \%$ versus $25 \%$ $(\mathrm{p}<0,005)$.

\section{Dokumentasjon}

Nesten alle (96\%) svarte at pasientens ønsker «som oftest» blir dokumentert $\mathrm{i}$ journalen. $30 \%$ svarte at det også noteres andre steder, for eksempel i palliativ plan og i brukermedvirkningsskjemaet.

Forberedende samtale og innkomstsamtale Ved et stort flertall av sykehjemmene (93\%) hadde man innkomstsamtale med pasient og/eller pårørende ved innleggelsen. Disse 
samtalene handlet oftest om praktiske spørsmål og pasientens livshistorie.

To tredeler svarte at de også tar opp spørsmål om behandling ved eventuell forverring av pasientens helsetilstand, det vil si et tema som er sentralt i det vi betegner som forberedende samtaler. I tillegg var det enkelte som nevnte henholdsvis forventningsavklaring og behandlingsavklaring i et åpent svaralternativ.

\section{Diskusjon}

Kort oppsummert indikerer resultatene at det ble gjennomført «forberedende samtaler» ved flere sykehjem i 2014 enn i 2007 (6), men at samtalene ble gjennomført svært ulikt og sjelden i samsvar med det som er anbefalt internasjonalt.

Vi vil i det videre drøfte tre temaer som fremstår som sentrale og viktige dersom sykehjemmene har intensjoner om å gjennomføre forberedende samtaler på en god måte: variasjoner i praksis, pasientens medvirkning og betydningen av sykehjemmets legedekning.

\section{Variasjoner i praksis}

Hvor ofte sykehjemmene gjennomfører slike samtaler, varierte sterkt. I tillegg viste resultatene forskjeller i samtalenes innhold, når de finner sted, hvem som deltar og hvordan de dokumenteres.

Den kanskje mest plausible forklaringen på dette er at sykehjemmene hadde utviklet ulike praksiser fordi det ikke er gitt nasjonale anbefalinger for dette fra helsemyndighetene. Variasjonen kan også skyldes at pasienter eller pårørende i ulik grad ønsker å delta i denne type samtaler (7).

Studien indikerte også ulikheter i hva som forstås med «forberedende samtaler». Resultatene tyder på at disse samtalene i stor grad enten foregår når pasienten blir dårligere eller når livet nærmer seg slutten, eventuelt i innkomstsamtalen.

To tredeler svarte at de i innkomstsamtalen - når pasienten som regel er helt ny på sykehjemmet - også tar opp spørsmål om behandling ved forverring av helsetilstanden. Selv om de hadde krysset av for dette i skjemaet, fikk vi inntrykk av at de foretar individuelle vurderinger av hva som er riktig tidspunkt, for eksempel ved at de vurderer om en slik samtale vil være for belastende for pasienten kort tid etter innkomst. Slike samtaler må tilbys når det oppleves som riktig for dem det gjelder.

I en studie fant man at de fleste pårørende syntes det var for tidlig å snakke om dette $\mathrm{i}$ innkomstsamtalen (7). For noen var overflytting til sykehjem så emosjonelt belastende at også det å snakke om den siste levetiden ble for mye. Andre fant det mer naturlig å vente med en slik samtale til pasientens helse ble ytterligere forverret (7). Hva som er «rett» tidspunktet for slike samtaler kan diskuteres, men i flere studier understrekes nødvendigheten av at helsepersonell er sensitive for hva pasienter og pårørende ønsker og at gode kommunikasjonsferdigheter er viktig $(3,13)$.

\section{Pasientens medvirkning}

I Norge finnes det ikke nasjonale retningslinjer for forberedende samtaler, men Helsedirektoratet anbefaler at sykehjemmet inviterer pasient og pårørende til denne type samtaler (5). Internasjonalt legges det gjerne vekt på følgende: å bli bedre kjent med pasienten før det er for sent, viktigheten av å få frem pasientens ønsker for behandling og pleie i tiden fremover, at det er en prosess med flere samtaler, å klargjøre pårørendes rolle og ikke kun legge vekt på døden eller livets siste fase $(12,16)$.

Våre funn bekreftes i andre nyere studier - sykehjemspasienter deltar bare unntaksvis i slike samtaler (7), selv når de er samtykkekompetente (17). Dette gir grunn til å stille spørsmål om hvordan pasientens rett til medbestemmelse ivaretas og hva helsepersonellets beslutninger er basert på.

At pasientene i liten grad deltar i samtalene, kan dels forstås på bakgrunn av at en høy andel sykehjemspasienter har kognitiv svikt. Samtidig vet vi at samtykkekompetansen varierer - selv om pasienten kan mangle kompetanse på noen områder, kan hun/han være samtykkekompetent på andre. Man kan også tenke seg at pasienter med redusert samtykkekompetanse i en del tilfeller bør få delta i samtalene sammen med nærmeste pårørende.

Studien vår indikerte at pårørende langt oftere var til stede i de forberedende samtalene enn pasientene selv. Dette samsvarer med det som er funnet $i$ andre studier (18, 19). Når pasienten ikke lenger er samtykkekompetent, skal de pårørende høres med hensyn til hva pasienten ville ha ønsket vedrørende behandling (20). En forutsetning for å basere beslutninger på pårørendes vurderinger er imidlertid at de kjenner til pasientens ønsker og preferanser, noe som faktisk ofte ikke er tilfellet (21-23). Det er derfor viktig å spørre direkte om hva de faktisk vet om pasientens ønsker og preferanser.

Vi vet at helsepersonell tidvis lar seg presse av pårørende til å fatte avgjørelser, ofte i retning av å vedlikeholde livsforlengende behandling, både på tvers av faglige vurdering av pasientens beste og hva de selv mener at pasienten ønsker $(19,24)$.

\section{Legedekningen}

Det var stor variasjon i legedekning mellom sykehjemmene, noe som er i samsvar med offentlig statistikk (25). I tråd med helse- politiske intensjoner har det vært en viss vekst i legedekningen det siste tiåret (26). Vår undersøkelse viste noe lavere timetall enn oppgitt $i$ ovennevnte database, der timetallet i 2014 var 0,49 timer per beboer per uke (25).

God legedekning synes både å øke hyppigheten av forberedende samtaler og pasientdeltagelsen. Tidligere har vi funnet at økt sykehjemslegedekning samvarierer med mindre bruk av tvang og at legene har en nøkkelfunksjon ved vurdering av samtykkekompetanse og tvang $(24,27)$. Sykehjemslegen synes å ha en viktig rolle i å styrke pasientens stemme når vanskelige spørsmål skal diskuteres og beslutninger fattes. Det er også legen som skal fatte den endelige beslutningen - $\mathrm{i}$ tråd med pasientens verdier og ønsker.

I en litteraturoversikt der man så på pasienters og pårørendes erfaringer med legens bidrag til god behandling, pleie og omsorg ved livets slutt, fant man at de ofte savnet en tilgjengelig og kompetent lege som aktivt deltok i samtaler og beslutninger rundt livets avslutning (28).

I en studie av samarbeid rundt døende pasienter fant Dreyer og medarbeidere (29) at ved sykehjem med god legedekning var det bedre samarbeid med sykepleierne om behandlingsspørsmål samt et bedre grunnlag for å gå inn i gode prosesser med pasient og pårørende enn i sykehjem med lav legedekning.

Også internasjonalt er utilfredsstillende legedekning i sykehjemmene blitt sett på som et vedvarende problem, blant annet assosiert med unødvendige sykehusinnleggelser, problemer med kommunikasjon og beslutningstaking og misnøye hos pasienter og pårørende (30).

\section{Svakheter ved studien}

En svarprosent på 57 var i underkant av det som er ønskelig og skaper usikkerhet om svarene. Begrensningen ligger i muligheten til å generalisere til alle norske sykehjem. Vi kan anta at det kanskje var en overhyppighet av sykehjem som praktiserer slike samtaler blant dem som har svart.

Spørreundersøkelsen var stilet til sykehjemmets ledelse, men med oppfordring om å innhente opplysninger hos andre, for eksempel avdelingssykepleier, dersom de var usikre på hva de skulle svare. Virksomhetsleder/enhetsleder har ansvar for hele sykehjemmet og har sjelden daglig kontakt med pasientene. Det er en svakhet ved undersøkelsen at vi ikke presiserte at den som har best kjennskap til slike samtaler, skulle besvare undersøkelsen.

Vi burde trolig også hatt med spørsmål om hvordan beslutninger ble dokumentert. På tross av disse svakhetene mener vi at den 
foreliggende studien gir verdifull informasjon om bruk av forberedende samtaler $\mathrm{i}$ norske sykehjem.

\section{Konklusjon}

Resultatene indikerer at det i stadig flere sykehjem gjennomføres en form for forberedende samtale, men tidspunkt, innhold i samtalene og hvem som deltar varierer. $\mathrm{Pa}$ sienten deltar sjelden i slike samtaler.

I lys av at diskusjonen om viktigheten av forberedende samtaler for bedre å ivareta pasientens ønsker og verdier er relativ ny i Norge, er variasjonen i praksis ikke overraskende. Det viser samtidig nødvendigheten av å løfte frem temaet i den helsepolitiske debatten. I tillegg bør man foreta studier som kan belyse gjennomføring og betydning av slike samtaler for pasienter, pårørende $\mathrm{og}$ ansatte.

Resultatene indikerer også behov for kompetanseoppbygging og nasjonale retningslinjer.

\section{Elisabeth Gjerberg (f. 1947)}

er sosiolog, dr.polit. og forsker.

Forfatter har fylt ut ICMJE-skjemaet og oppgir ingen interessekonflikter.

\section{Lillian Lillemoen (f. 1951)}

er sykepleier, dr.polit. og forsker.

Forfatter har fylt ut ICMJE-skjemaet og oppgir ingen interessekonflikter.

\section{Kristin Weaver (f. 1977)}

har en mastergrad i nordamerikanske studier og er prosjektkoordinator.

Forfatter har fylt ut ICMJE-skjemaet og oppgir ingen interessekonflikter.

\section{Reidar Pedersen (f. 1973)}

er lege og filosof, professor i medisinsk etikk og leder for Senter for medisinsk etikk. Forfatter har fylt ut ICMJE-skjemaet og oppgir ingen interessekonflikter.

\section{Reidun Førde (f. 1950)}

er lege og professor i medisinsk etikk. Forfatter har fylt ut ICMJE-skjemaet og oppgir ingen interessekonflikter.

\section{Litteratur}

1. Folkehelseinstituttet. D3: Dødsfall etter dødssted. http://statistikkbank fhi.no/dar/ (19.1.2017).

2. Selbæk G, Kirkevold $\emptyset$, Engedal K. The prevalence of psychiatric symptoms and behavioural disturbances and the use of psychotropic drugs in Norwegian nursing homes. Int J Geriatr Psychiatry 2007: 22: 843-9.

3. Mullick A, Martin J, Sallnow L. An introduction to advance care planning in practice. BMJ 2013; 347 f6064.

4. Stewart F, Goddard C, Schiff R et al. Advanced care planning in care homes for older people: a qualitative study of the views of care staff and families. Age Ageing 2011; 40: 330-5

5. Helsedirektoratet. Nasjonal veileder for beslutninger om livsforlengende behandling hos alvorlig syke og døende. https://helsedirektoratet.no/ Lists/Publikasjoner/Attachments/67/IS-2091 Beslutningsprosesser-ved-begrensning-avlivsforlengende-behandling pdf 2013 (19.1.2017)

6. Gjerberg E, Førde R, Bjørndal A. Staff and family relationships in end-of-life nursing home care. Nurs Ethics 2011; 18: 42-53.

7. Gjerberg E, Lillemoen L, Førde R et al. End-of-life care communications and shared decision-making in Norwegian nursing homes-experiences and perspectives of patients and relatives. BMC Geriatr 2015; 15: 103

8. Friis $P$, Førde R. Forhåndssamtaler med geriatriske pasienter. Tidsskr Nor Legeforen 2015; 135: 233-5.

9. Brinkman-Stoppelenburg A, Rietjens JA, van der Heide A. The effects of advance care planning on end-of-life care: a systematic review. Palliat Med 2014: 28: 1000-25.

10. Houben CH, Spruit MA, Groenen MT et al. Efficacy of advance care planning: a systematic review and meta-analysis. J Am Med Dir Assoc 2014 15: 477-89.

11. Robinson L, Dickinson C, Rousseau N et al. A systematic review of the effectiveness of advance care planning interventions for people with cognitive impairment and dementia. Age Ageing 2012; 41 : 263-9.

12. Sharp T, Moran E, Kuhn I et al. Do the elderly have a voice? Advance care planning discussions with frail and older individuals: a systematic literature review and narrative synthesis. Br J Gen Pract 2013; 63: e657-68.

13. van der Steen JT, van Soest-Poortvliet MC, HallieHeierman $\mathrm{M}$ et al. Factors associated with initiation of advance care planning in dementia: a systematic review. J Alzheimers Dis 2014: 40: 743-57.

14. Wickson-Griffiths A, Kaasalainen S, Ploeg J et al. A review of advance care planning programs in long-term care homes: are they dementia friendly? Nurs Res Pract 2014; 2014: 875897

15. Flo $E$, Husebo BS, Bruusgaard $P$ et al. A review of the implementation and research strategies of advance care planning in nursing homes. BMC Geriatr 2016; 16: 24

16. Séchaud L, Goulet C. Morin D et al. Advance care planning for institutionalised older people: an integrative review of the literature. Int J Older People Nurs 2014; 9: 159-68.

17. Dreyer A, Førde R, Nortvedt P. Life-prolonging treatment in nursing homes: how do physicians and nurses describe and justify their own practice? $\mathrm{J}$ Med Ethics 2010; 36: 396-400.
18. Dreyer A, Førde R, Nortvedt P. Autonomy at the end of life: life-prolonging treatment in nursing homes - relatives' role in the decision-making process. J Med Ethics 2009; 35: 672-7.

19. Romøren M, Pedersen R, Førde R. How do nursing home doctors involve patients and next of kin in end-of-life decisions? A qualitative study from Norway. BMC Med Ethics 2016; 17: 5

20. Helse- og omsorgsdepartementet. Lov om pasientog brukerrettigheter. https://lovdata.no/dokument/ NL/lov/1999-07-02-63 2016Available from: URL: https://lovdata.no/dokument/NL/lov/ 1999-07-02-63 (19.1.2017)

21. Black BS, Fogarty LA, Phillips $\mathrm{H}$ et al. Surrogate decision makers understanding of dementia patients' prior wishes for end-of-life care. J Aging Health 2009; 21: 627-50.

22. Petriwskyj A, Gibson A, Parker D et al. A qualitative metasynthesis: family involvement in decision making for people with dementia in residential aged care. Int J Evid-Based Healthc 2014; 12: 87-104.

23. Shalowitz DI, Garrett-Mayer E, Wendler D. The accuracy of surrogate decision makers: a systematic review. Arch Intern Med 2006; 166: 493-7.

24. Gjerberg E, Førde R, Pedersen R et al. Ethical challenges in the provision of end-of-life care in Norwegian nursing homes. Soc Sci Med 2010; 71: 677-84

25. HelseNorge. Legetimer for beboer i sykehjem. https://helsenorge.no/Kvalitetsindikatorer/ kvalitetsindikator-pleie-og-omsorg/legetimerfor-beboer-i-sykehjem 2015 (19.1.2017).

(26) Sosial- og helsedirektoratet. Normering av legetjenester i sykehjem. Report No.: 1S-1293. Oslo: Sosial-og helsedirektoratet, 2005.

27. Pedersen R, Hem MH, Gjerberg E et al. Bruk av tvang i sykehjem etter ny lovgivning. Tidsskr Nor Legeforen 2013; 133: 1935-9.

28. Fosse A, Schaufel MA, Ruths S et al. End-of-life expectations and experiences among nursing home patients and their relatives-a synthesis of qualitative studies. Patient Educ Couns 2014; 97: 3-9.

29. Dreyer A, Førde R, Nortvedt P. Ethical decisionmaking in nursing homes: influence of organizational factors. Nurs Ethics 2011; 18: 514-25.

30. Shield RR, Wetle T, Teno J et al. Physicians «missing in action»: family perspectives on physician and staffing problems in end-of-life care in the nursing home. J Am Geriatr Soc 2005; 53: 1651 -7.

Mottatt 30.3. 2016, første revisjon innsendt 22.9. 2016, godkjent 19.1. 2017. Redaktør: Tor Rosness. 